\title{
PENGARUH KECEMASAN MATEMATIKA DAN PROKRASTINASI AKADEMIK SISWA TERHADAP HASIL BELAJAR MATEMATIKA SISWA KELAS VIII SMP NEGERI 7 BALIKPAPAN
}

\author{
Zuraidah $^{\mathrm{a}}$, Tri Hariyati Nur Indah Sari ${ }^{\mathrm{b}}$, Suci Yuniarti \\ ${ }^{a}$ Program Studi Pendidikan Matematika FKIP Uniba \\ Jl. Pupuk Raya Kel. Damai Bahagia Balikpapan, zuraidahiskandar14@gmail.com \\ ${ }^{\mathrm{b}}$ Program Studi Pendidikan Matematika FKIP Uniba \\ Jl. Pupuk Raya Kel. Damai Bahagia Balikpapan, tri.hariyati.nis@ uniba-bpn.ac.id \\ ${ }^{c}$ Program Studi Pendidikan Matematika FKIP Uniba \\ Jl. Pupuk Raya Kel. Damai Bahagia Balikpapan, suci.yuniarti@uniba-bpn.ac.id
}

\begin{abstract}
ABSTRAK
Adanya pandangan negatif siswa terhadap matematika menimbulkan kecemasan dan prokrastinasi akademik. Penelitian ini bertujuan untuk mengetahui pengaruh kecemasan matematika dan prokrastinasi akademik terhadap hasil belajar matematika siswa kelas VIII SMP Negeri 7 Balikpapan. Pendekatan penelitian yang digunakan adalah pendekatan kuantitatif dengan metode survey. Populasi dalam penelitian ini adalah seluruh siswa kelas VIII SMP Negeri 7 Balikpapan yang berjumlah 362 siswa dan sampel penelitian berjumlah 72 siswa. Teknik pengambilan sampel menggunakan cluster random sampling. Instrumen yang digunakan adalah kuesioner dan tes. Teknik analisis data yang digunakan adalah analisis regresi berganda dengan uji simultan (uji-F) dan uji parsial (uji-t). Hasil penelitian diperoleh nilai signifikan 0,000<0,05 maka dapat disimpulkan adanya pengaruh kecemasan matematika dan prokrastinasi akademik secara signifikan terhadap hasil belajar siswa kelas VIII SMP Negeri 7 Balikpapan. Hasil penelitian menunjukkan kecemasan matematika berpengaruh terhadap hasil belajar matematika secara signifikan dengan nilai signifikansi $0,023<0,05$. Kemudian prokrastinasi akademik berpengaruh terhadap hasil belajar matematika secara signifikan dengan nilai signifikansi $0,012<0,05$.
\end{abstract}

Kata Kunci : kecemasan matematika, prokrastinasi akademik, hasil belajar matematika.

\section{ABSTRACT}

The existence of students' negative views on mathematics causes anxiety and procrastination. This study aims to determine the effect of mathematical anxiety and academic procrastination on mathematics learning outcomes in class VIII SMP Negeri 7 Balikpapan. The research approach used is a quantitative approach with survey method. The population in this study were all eighth grade students of SMP Negeri 7 Balikpapan, as many as 362 students and a total sample of 72 students. The sampling technique uses cluster random sampling. Instruments used in this study was questionnaires and test. The data analysis technique used is multiple regression analysis with simultaneous test ( $\mathrm{F}$ test) and partial test ( $\mathrm{t}$-test). The results obtained a significant value of $0,000<0,05$, it could be concluded that there was a significant influence of mathematics anxiety and academic procrastination on mathematics learning outcomes of VIII grade students of SMP Negeri 7 Balikpapan. The results of the study showed that mathematics anxiety had a significant effect on mathematics learning outcomes with a significance value of $0,023<0,05$. Then, academic procrastination has a significant effect on mathematics learning outcomes with a significance value of $0,012<0,05$.

Keyword(s): mathematical anxiety, academic procrastination, mathematics learning outcomes. 


\section{PENDAHULUAN}

Pendidikan adalah serangkaian interaksi manusia dengan lingkungan yang dilakukan secara terus-menerus dan disisi lain pendidikan menunjuk pada hasil interaksi manusia dengan lingkungannya berupa perubahan dan peningkatan kognisi, afektif dan psikomotorik (Ahmadi, 2014, p. 7). Pendidikan selain sebagai proses, juga sebagai hasil dari perubahan yang terjadi dalam interaksi. Pendidikan merupakan salah satu indikator sumber daya manusia yang berkualitas dan dapat dilihat melalui hasil belajar, maka berbagai usaha apapun akan dilakukan oleh setiap sekolah untuk mendapatkan hasil belajar yang baik.

Hasil belajar adalah perubahan tingkah laku yang telah dicapai siswa dari suatu interaksi yang mengarah pada penguasaan pengetahuan, keterampilan dan sikap. Ekawati (2015, p. 164) mengungkapkan hasil belajar dipengaruhi oleh dua faktor yaitu faktor eksternal dan faktor internal. Salah satu faktor yang mempengaruhi hasil belajar yaitu ketidakmampuan siswa dalam tugas dan ketidaksiapan siswa dalam kewajiban belajar sehingga tidak menggunakan waktu secara efektif, mengulur waktu dan melakukan prokrastinasi akademik. Zakiyah, Hidayati \& Setyawan (2010, p. 159) mengungkapkan prokrastinasi akademik adalah suatu faktor gejala kecenderungan yang menunda-nunda penyelesaian suatu tugas atau pekerjaan sehingga seseorang gagal menyelesaikan tugas tersebut tepat pada waktunya.

Tinggi rendahnya perilaku prokrastinasi akademik siswa banyak dipengaruhi oleh faktor pembentuknya. Perilaku prokrastinasi akademik terbentuk dan berkembang dalam proses sosialisasi yang bisa dimulai dari keluarga, akan diperkuat lingkungan masyarakat dan lingkungan sekolah sehingga mempengaruhi rendahnya hasil belajar siswa. Ackerman \& Gross (Triana, 2013, p. 281) mendeskripsikan faktor prokrastinasi akademik diantaranya adalah defisiensi regulasi diri, motivasi yang rendah, pusat kendali diri eksternal, perfeksionis, manajemen waktu yang lemah, rendahnya kontrol diri (self control) dan kecemasan.

Kecemasan dianggap sebagai salah satu faktor penghambat dalam belajar yang dapat menggangu kinerja fungsi kognitif seseorang dalam berkonsentarsi, mengingat, pembentukan konsep, dan pemecahan masalah (Ekawati, 2015, p. 165). Semakin tinggi kecemasan seseorang maka semakin tinggi pula frekuensi munculnya gejalagejala kecemasan dan semakin parah reaksi yang ditimbulkanya. Dacey (Ekawati, 2015, p. 165) mengungkapkan kecemasan matematika siswa dapat dikenali melalui tinjauan pada tiga komponen antara lain :

1. Komponen Psikologi 
Berupa kegelisahan, gugup, tegang, cemas, rasa tidak aman, takut dan cepat terkejut.

\section{Komponen Fisiologis}

Berupa jantung berdebar, keringat dingin pada telapak tangan dan tekanan darah meninggi.

\section{Komponen Sosial}

Berupa perilaku yang ditunjukkan oleh individu dilingkungannya berupa tingkah laku dan gangguan tidur.

Keadaan ini pada akhirnya menyebabkan semakin tidak efektif dan efesien kegiatan belajar yang dilakukan oleh siswa. Oleh karena itu, tujuan penelitian ini yaitu untuk mengetahui pengaruh kecemasan matematika dan prokrastinasi akademik siswa terhadap hasil belajar matematika siswa kelas VIII SMP Negeri 7 Balikpapan Tahun Pelajaran 2017/2018.

\section{METODE PENELITIAN}

Jenis penelitian yang digunakan pada penelitian ini adalah kuantitatif menggunakan metode survey. Zikmund (Noor, 2015, pp. 2930) metode survei adalah satu bentuk teknik penelitian dimana informasi dikumpulkan dari sejumlah sampel berupa orang, melalui pertanyaan-pertanyaan, merupakan metode yang digunakan sebagai kategori umum penelitian yang menggunakan kuesioner dan wawancara. Adapun yang menjadi lokasi dari tempat penelitian ini adalah SMP Negeri 7 Balikpapan yang berlokasi di jalan Penegak No.67 Rt.33 Kelurahan Damai, Kecamatan
Balikpapan Kota. Populasi dalam penelitian ini adalah seluruh siswa kelas VIII SMP Negeri 7 Balikpapan yang berjumlah 362 siswa.

Metode penetapan sampel yang digunakan dalam penelitian ini adalah cluster random sampling. Peneliti melakukan pengambilan secara acak sebanyak dua gulungan kertas dari dalam kotak. Dari cara tersebut, peneliti memperoleh sampel kelas VIII-H dengan jumlah 37 siswa dan VIII-J dengan jumlah 35 siswa. Teknik pengumpulan data yang digunakan dalam penelitian ini adalah kuesioner dan tes. Dalam penelitian ini kuesioner digunakan untuk mengumpulkan data mengenai kecemasan matematika dan prokrastinasi akademik sedangkan tes digunakan untuk mengetahui hasil belajar matematika siswa pada materi Bangun Ruang Sisi Datar yang terdiri dari 6 soal essai. Sebelum Diberikan Kepada Siswa, Instrumen diujikan terlebih dahulu untuk mengetahui kelayakan instrumen.

\section{HASIL DAN PEMBAHASAN}

\section{Hasil Deskripsi Data Kecemasan Matematika}

Variabel kecemasan matematika dengan sampel 68 siswa diperoleh hasil rentang nilai (range) sebesar 41; nilai terendah (minimum) sebesar 51; nilai tertinggi (maximum) sebesar 92; penjumlahan keseluruhan (sum) sebesar 4862; dengan rata-rata (mean) 71,50; simpangan baku 
(std.deviation) sebesar 8,247; dan varian (variance) sebesar 68,105.

\section{Hasil Deskripsi Data Prokrastinasi Akademik}

Variabel prokrastinasi akademik dengan sampel 68 siswa diperoleh hasil rentang nilai (range) sebesar 26; nilai terendah (minimum) sebesar 54; nilai tertinggi (maximum) sebesar 80; penjumlahan keseluruhan (sum) sebesar 4567; dengan rata-rata (mean) 67,16; simpangan baku (std.deviation) sebesar 5,682; dan varian (variance) sebesar 32,287.

\section{Deskripsi Data Hasil Belajar Matematika}

Variabel prokrastinasi akademik dengan sampel 68 siswa diperoleh hasil rentang nilai (range) sebesar 60; nilai terendah (minimum) sebesar 10; nilai tertinggi (maximum) sebesar 70; penjumlahan keseluruhan (sum) sebesar 3051; dengan rata-rata (mean) 44,86; simpangan baku (std.deviation) sebesar 18,049; dan varian (variance) sebesar 325,788.

\section{HASIL PENELITIAN}

\section{1) Uji Prasyarat}

Setelah semua data yang dikumpulkan sudah terkumpul, data tersebut kemudian harus memenuhi uji prasyarat yaitu uji normalitas, uji linieritas, uji multikolinieritas dan uji heterokedastisitas.

\section{a. Uji Normalitas}

Tabel 1. Hasil Perhitungan Uji Normalitas

\begin{tabular}{ccc} 
Variabel & \multicolumn{2}{c}{ Kolmogorov Smirnov } \\
\cline { 2 - 3 } & Statistik & Signifikansi \\
\hline Nilai Residual & 0,105 & 0,060 \\
\hline
\end{tabular}

Nilai statistik diperoleh 0,105 dan nilai signifikan diperoleh $0,060>0,05$. Maka dapat disimpulkan $H_{0}$ diterima atau nilai residual berdistribusi normal.

\section{b. Uji Linieritas}

Tabel 2. Hasil Perhitungan Uji Linieritas

\begin{tabular}{ccc}
\hline Variabel & Sig. & Ket. \\
\hline $\mathrm{X}_{1}$ dengan $\mathrm{Y}$ & 0,668 & Linier \\
$\mathrm{X}_{2}$ dengan $\mathrm{Y}$ & 0,339 & Linier \\
\hline
\end{tabular}

Variabel kecemasan matematika dengan nilai signifikan 0,668>0,05 maka, dapat disimpulkan terdapat hubungan linier kecemasan matematika dengan hasil belajar matematika. Sedangkan untuk variabel prokrastinasi akademik dengan nilai signifikan $0,339>0,05$ maka, dapat disimpulkan terdapat hubungan linier prokrastinasi akademik dengan hasil belajar matematika.

\section{c. Uji Multikolinieritas}

Tabel 3. Hasil Perhitungan Uji Multikolinieritas

\begin{tabular}{cccc}
\hline Variabel & VIF & Tolerance & Ket. \\
\hline $\mathrm{X}_{1}$ & 0,668 & 0,907 & Tidak \\
dengan & & & terjadi \\
$\mathrm{X}_{2}$ & & & Multikolin \\
& & & eritas \\
\hline
\end{tabular}

Variabel kecemasan matematika dan prokrastinasi akademik dengan nilai VIF sebesar $1,103<10$ dan tolerance $0,907<$ 0,1 . Hal ini menunjukkan bahwa tidak terjadi multikolinieritas antar variabel $X 1$ dan $X 2$ dalam regresi. 
d. Uji Heterokesdatisitas

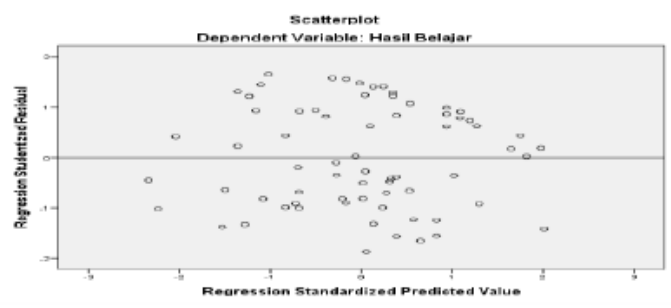

Gambar 1. Grafik Scatterplots

Pada gambar 1 diperoleh titik-titik yang membentuk pola tidak teratur, tidak bergelombang, tidak menyebar dan menyempit. Maka, dapat disimpulkan tidak terjadi heterokesdastisitas.

\section{2) Uji Hipotesis}

Setelah semua uji prasyarat terpenuhi, kemudian dilanjutkan dengan menguji hipotesis menggunakan uji teknik analisis berganda, uji simultan secara bersama-sama (uji-F) dan uji parsial (uji-t).

\section{a. Uji Simultan(Uji-F)}

Tabel 4. Hasil Perhitungan Uji Simultan (Uji-F)

\begin{tabular}{cccc}
\hline Pengaruh & $\mathbf{F}_{\text {hitung }}$ & Sig & Ket. \\
\hline $\mathrm{X}_{1}$ dan & 8,739 & 0,000 & Terdapat \\
$\mathrm{X}_{2}$ & & & pengaruh \\
terhadap & & & secara \\
$\mathrm{Y}$ & & & bersama-sama \\
\hline
\end{tabular}

Diperoleh nilai signifikan $0,000<$ 0,05 maka, dapat disimpulkan terdapat pengaruh kecemasan matematika dan prokrastinasi akademik siswa secara bersamasama terhadap hasil belajar matematika kelas VIII SMP Negeri 7 Balikpapan Tahun Pelajaran 2017/2018. b. Uji Parsial (Uji-t)

\begin{tabular}{|c|c|c|c|}
\hline Pengaruh & $\mathbf{t}_{\text {hitung }}$ & Sig & Ket. \\
\hline $\begin{array}{c}\mathrm{X}_{1} \\
\text { terhadap } \\
\mathrm{Y}\end{array}$ & $-2,328$ & 0,023 & $\begin{array}{c}\text { Terdapat } \\
\text { pengaruh } \\
\text { secara parsial }\end{array}$ \\
\hline $\begin{array}{c}\mathrm{X}_{2} \\
\text { terhadap } \\
\mathrm{Y}\end{array}$ & $-2,596$ & 0,012 & $\begin{array}{c}\text { Terdapat } \\
\text { pengaruh } \\
\text { secara parsial }\end{array}$ \\
\hline
\end{tabular}

Variabel kecemasan matematika terhadap hasil belajar matematika siswa diperoleh nilai signifikan $0,023<0,05$ maka, dapat disimpulkan bahwa terdapat pengaruh kecemasan matematika terhadap hasil belajar matematika siswa kelas VIII SMP Negeri 7 Balikpapan Tahun Pelajaran 2017/2018.

Sedangkan pada variabel prokrastinasi akademik terhadap hasil belajar matematika diperoleh nilai signifikan $0,012<0,05$ maka, dapat disimpulkan bahwa terdapat pengaruh prokrastinasi akademik terhadap hasil belajar matematika siswa kelas VIII SMP Negeri 7 Balikpapan Tahun Pelajaran 2017/2018.

\section{PEMBAHASAN}

Hasil penelitian menunjukkan bahwa kecemasan matematika dan prokrastinasi akademik berpengaruh signifikan terhadap hasil belajar matematika. Hasil uji simultan (uji-F) diperoleh nilai signifikan 0,000 < 0,05 maka $H_{0}$ ditolak, hal ini berarti bahwa terdapat pengaruh kecemasan matematika 
dan prokrastinasi akademik siswa secara bersama-sama terhadap hasil belajar matematika.

Hal ini menunjukkan bahwa kecemasan matematika dan prokrastinasi akademik memiliki pengaruh terhadap hasil belajar matematika siswa. Apabila kecemasan matematika dan prokrastinasi akademik siswa meningkat maka hasil belajar matematika siswa cenderung menurun. Sedangkan jika kecemasan matematika dan prokrastinasi akademik siswa menurun maka hasil belajar matematika siswa cenderung meningkat. Dari penemuan hasil analisis dikuatkan dengan teori Ackerman \& Gross (Sutjipto, 2012) yang menyatakan bahwa semakin tinggi kecemasan matematika dan prokrastinasi akademik yang dimiliki siswa, maka akan semakin rendah hasil belajar siswa. Maka pada penelitian ini dapat disimpulkan bahwa kecemasan matematika dan prokrastinasi akademik memiliki pengaruh yang terhadap hasil belajar matematika siswa.

Pada hasil uji parsial (uji-t) variabel kecemasan matematika terhadap hasil belajar matematika diperoleh terdapat pengaruh kecemasan matematika terhadap hasil belajar matematika siswa dengan nilai signifikan $0,023<0,05$ maka $H_{0}$ ditolak, sehingga dapat disimpulkan bahwa terdapat pengaruh kecemasan matematika terhadap hasil belajar matematika. Hal ini menunjukkan bahwa kecemasan matematika berpengaruh terhadap hasil belajar matematika siswa. Apabila kecemasan matematika meningkat maka hasil belajar matematika siswa cenderung menurun. Sedangkan jika kecemasan matematika menurun maka hasil belajar siswa cenderung meningkat.

Dari penemuan hasil analisis dikuatkan dengan penelitian Masruroh \& Reza (2015, p. 184) yang menyatakan bahwa jika kecemasan siswa pada matematika tinggi maka hasil belajar matematika rendah dan jika kecemasan siswa pada matematika rendah maka hasil belajar matematika tinggi. Maka pada penelitian ini dapat disimpulkan bahwa kecemasan matematika memiliki pengaruh yang terhadap hasil belajar matematika siswa.

Pada hasil uji parsial (uji-t) variabel prokrastinasi akademik terhadap hasil belajar matematika diperoleh terdapat pengaruh prokrastinasi akademik terhadap hasil belajar matematika dengan nilai signifikan $0,012<0,05$ maka $H_{0}$ ditolak, sehingga dapat disimpulkan bahwa terdapat pengaruh prokrastinasi akademik terhadap hasil belajar matematika. Hal ini menunjukkan bahwa prokrastinasi akademik berpengaruh terhadap hasil belajar matematika siswa. Apabila prokrastinasi akademik meningkat maka hasil belajar matematika siswa cenderung menurun. 
Sedangkan jika prokrastinasi akademik menurun maka hasil belajar siswa cenderung meningkat.

Dari penemuan hasil analisis dikuatkan dengan penelitian Zakiyah, Hidayati, \& Setyawan (2010, p. 156) yang menyatakan bahwa jika prokrastinasi akademik tinggi maka hasil belajar matematika siswa rendah dan sebaliknya. Maka pada penelitian ini dapat disimpulkan bahwa prokrastinasi akademik memiliki pengaruh yang terhadap hasil belajar matematika siswa.

\section{KESIMPULAN}

Berdasarkan hasil penelitian dan pembahasan, maka dapat ditarik kesimpulan sebagai berikut :

1. Terdapat pengaruh kecemasan matematika dan prokrastinasi akademik siswa secara bersama-sama terhadap hasil belajar matematika siswa kelas VIII SMP Negeri 7 Balikpapan Tahun Pelajaran 2017/2018.

2. Terdapat pengaruh yang signifikan kecemasan matematika terhadap hasil belajar matematika siswa kelas VIII SMP Negeri 7 Balikpapan Tahun Pelajaran 2017/2018.

3. Terdapat pengaruh yang signifikan prokrastinasi akademik terhadap hasil belajar matematika siswa kelas VIII SMP Negeri 7 Balikpapan Tahun Pelajaran 2017/2018.

\section{DAFTAR PUSTAKA}

Ahmadi, R. (2014). Pengantar Pendidikan Asas dan Filsafat Pendidikan. Yogyakarta: AR-RUZZ MEDIA.

Ekawati, A. (2015). Pengaruh Kecemasan terhadap Hasil Belajar Matematika Siswa Kelas VII SMP Negeri 13 Banjarmasin. Jurnal Pendidikan Matematika, Vol. 1(3). pp.164-169.

Masruroh , L., \& Reza, M. D. (2015). Pengaruh Kecemasan Siswa pada Matematika terhadap Hasil Belajar Matematika di SMP. Jurnal Pendidikan Matematika, Vol. 3(2). pp.175-186.

Noor, M. (2015). Memotret Data Kuantitatif. Semarang: CV. Duta Nusindo Semarang.

Sutjipto, R. C. (2012). Prokrastinasi Dan Kecemasan Pada Mahasiswa Psikologi Universitas Surabaya. Jurnal Ilmiah Mahasiswa Universitas Surabaya, Vol. 1(1). pp.283-303.

Triana, K. A. (2013). Hubungan Antara Orientasi Masa Depan Dengan Prokrastinasi Dalam Menyusun Skripsi Pada Mahasiswa Fakultas Ilmu Sosial dan Ilmu Politik (Fisipol) Universitas Mulawarman Samarinda. eJournal Psikologi, Vol. 1(3). pp.280-291.

Zakiyah, N., Hidayati, F. R., \& Setyawan, I. (2010). Hubungan antara Penyesuaian Diri dengan Prokrastinasi Akademik Siswa Sekolah Berasrama SMP Negeri 3 Peterongan Jombang. Jurnal Psikologi Undip, Vol. 8(2). pp.157167. 